\title{
Aleister Crowley on Drugs
}

Christopher Partridge

\begin{abstract}
While much has been written about the life, work and influence of Aleister Crowley, relatively little attention has been directed to his drug use. This is a little surprising because, not only did he become addicted to heroin, but he incorporated psychoactive substances in his occult work, discussed their psychological effects, commented on drug-related social issues, critiqued contemporary drug legislation, published drug literature, and even translated Charles Baudelaire's 'Poem of Hashish.' This article discusses his thought on drugs and religious experience and suggests that they were, largely because of his addiction, a more important force in his life than has thus far been acknowledged.
\end{abstract}


Aleister Crowley was the epitome of the fin de siècle occultist. He gloried in accusations of Satanism, delighted in tabloid vilifications of him as 'A Wizard of Wickedness,' 'the Wickedest Man in the World,' and the 'King of Depravity,' and, with reference to 'the

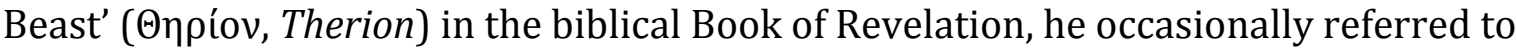
himself as 'the Great Beast' or the 'Master Therion.' In several respects, he was a good example of 'the tragic generation' eulogized by W.B. Yeats. While Yeats did not, of course, have Crowley in mind-considering him to be an 'unspeakable mad person' (quoted in Kaczynski 2010: 66)—the significant personal wealth Crowley had inherited ${ }^{1}$ afforded him the space to embrace decadence in much the same way that Joris-Karl Huysmans recounts the perverse pleasures of the wealthy and reclusive aesthete Des Esseintes in his 1884 novel À rebours (trans. 1959). Likewise, just as Yeats's tragic generation was haunted by disillusionment, ennui and despair, often as a result of the persistent quest for intense experiences, so too there is a shadow across Crowley's life. His exhaustive search for moments of ecstasy did not always end happily and, in the case of drugs, led to the debilitating pain and ignominy of addiction.

While there are references to drugs and short discussions of their effects scattered throughout his work, only a small percentage of the Crowleyan corpus specifically addresses the subject, the principal works being: three essays on the psychoactive significance of drugs, 'The Psychology of Hashish' (1909), 'Absinthe-The Green Goddess' (1917a), and 'Ethyl Oxide' (1923)²; three discussions of legislation and addiction, 'Cocaine' (1917b), 'The Great Drug Delusion' (1922a), and 'The Drug Panic' (1922b); a diary of his struggle with addiction, 'Liber XVIII: The Fountain of Hyacinth' (1921)33 a short story, 'The Drug' (1909); and a hastily written novel in 1922-the principal aim of which was to make money for drugs-largely based on his own experiences and relationships, Diary of a Drug Fiend (1979). Moreover, gathered together under the title 'The Herb Dangerous,' in successive issues of his journal The Equinox, ${ }^{4}$ he published, firstly, 'A Pharmaceutical Study of Cannabis Sativa' (March, 1909) by E.P. Whineray-a London pharmacist who often supplied Crowley with drugs - secondly, his essay 'The Psychology of Hashish' (September, 1909), thirdly, his own translation of Charles Baudelaire’s 'The Poem of Hashish' (March, 1910), and finally, extracts from Fitz Hugh Ludlow's The Hasheesh Eater (September, 1910). 
While there is very little significant published research into Crowley's use of psychoactives, and while he obscured the tyranny of his addiction in much of his writing, nevertheless it is clear that drugs were incorporated into his occult theory and practice. Indeed, this article suggests that, largely because of his addiction, they were more important to him than is typically acknowledged in Crowley scholarship.

\section{Scientific illuminism and Thelemic philosophy}

Reading through this material, it quickly becomes apparent that, for all their problematic baggage, Crowley was impressed by the ability of drugs to produce what the psychologist Abraham Maslow would later call 'peak experiences'-'an illumination, a revelation, an insight' (1964: 183). Consequently, as Martin Booth discusses, he came to believe that "the taking of drugs—at least, the right "magical" drugs—should precede all magical ceremonies because they made access to mystical experiences all the easier.' Moreover, 'he believed that they were genuinely magical and he made use of the way in which they enabled him to re-examine his basic beliefs and values from a new point of view, reassessing the world from a magical and mystical perspective. One of the primary aims of his life was the extension of his consciousness by whatever means, applied separately or in combination' (Booth 2000: 102). More specifically, they were treated as powerful technologies in the service of 'scientific illuminism,' the core idea behind which was distilled into the motto, 'the method of science; the aim of religion."5 Essentially, arguing that the approaches of both science and religion had failed in their attempts to access the true nature of reality, Crowley sought to develop a via media in the form of a system that combined the methodologies of both. Psychoactive substances were useful in such a system because, under the right conditions, they were able to induce reproducible (i.e. 'scientific') moments of revelation. That is to say, apart from being peculiarly effective in the production of altered states, they equipped the user with a certain level of control. One could, with reasonable accuracy, determine, not only the time and place of a mystical experience, but also its intensity and nature. As such, psychoactives were enormously appealing to a mystic wanting to apply the scientific method to occult practice. Indeed, he was particularly impressed and influenced by the research of William James into nitrous oxide intoxication and induced mysticism. 'Since 1898,' he tells us, 'I have been principally occupied in studying the effects of various drugs upon the human organism, with special reference to the parallelisms between 
psychical phenomena of drug-neuroses, insanities, and mystical illuminations. The main object has been to see whether it is possible to produce the indubitably useful (see William James, Varieties of Religious Experience) results of "ecstasy" in the laboratory' (Crowley 1922a: 573). While Crowley was, of course, no James, this does indicate something of the direction of his thought regarding the use of drugs in occult practice.

This brings us to his Thelemic philosophy. Keenly focused on the significance of 'the will' ( $\theta \varepsilon \dot{\lambda} \eta \mu \alpha$, thelema), he famously insisted that "Do what thou wilt shall be the whole of the law." "Love is the law, love under will." "There is no law beyond Do what thou wilt"' (Crowley 1976: 9). Central to this broadly egoistic philosophy was the notion of the 'True Will,' which expressed his conviction that all beings have their own purpose to which, at the expense of all else, they must devote themselves. This is not to say that Crowley's egoism advocated simply doing only what one wants, but rather it insisted on the discovery of one's purpose in life-in accordance with the cosmic laws of the universe-followed by the fulfilling of that purpose. In short, one's True Will must be identified and realized. 'Magick' - the term he used for his system, which he defined as 'the Science and Art of causing Change to occur in conformity with the Will' (2000: 126)-enabled the identification and realization of the True Will (see, Crowley 1976: 10). Flowing from this, his declaration that 'every man and woman is a star' (1976: 19) suggested the potentiality within all of us for glorification. As long as we follow our proper course, the struggles of life that inhibit progress toward glorification will dissolve. Although, again, Crowley would discover that drugs can lead to a dulled and diminished will, he was also convinced that, in the right hands (and head), they could be incorporated into the Thelemic system.

I have been sucking up the vapour of Ether for a few moments, and all common things are touched with beauty. So, too with opium and cocaine, calm, peace, happiness, without special object, result from a few minutes of those drugs. What clearer proof that all depends on state of mind, that it is foolishness to alter externals? A million spent on objets d'art would not have made this room as beautiful as it is just now-and there is not one beautiful thing in it, except myself. Man is a little lower than the angels; one step, and all glory is ours (Crowley, quoted in Booth 2000: 334-335). 
Again, concerning cocaine, while he acknowledges the shadow of addiction, nevertheless, he argues that, used carefully, it can be a valuable technology of transcendence: 'the happiness of cocaine is not passive or placid as that of the beasts; it is self-conscious. It tells man what he is, and what he might be; it offers him the semblance of divinity, only that he may know himself a worm. It awakes discontent so acutely that never shall it sleep again. It creates hunger' (Crowley 1917b: 292).

If drugs are able to create a hunger for glorification and mystical experience, then, as far as Crowley was concerned, they are an effective means to an important end. This is essentially Israel Regardie's thesis concerning Crowley's understanding of the esoteric significance drugs. An influential interpreter of Crowleyan magic, having worked as his secretary for four years, he argues that he was primarily interested in their ability to induce 'a foretaste or some adumbration of the mystical experience towards which he was focusing all his energies' (Regardie 1994: 23). That is to say, Crowley believed that, 'if the Neophyte could taste the glory and the ineffability of his goals by means of an introductory dose of hashish, he would then be willing to embark upon a lifelong program of self-discipline to make the divine an intrinsic part of his being' (Regardie 2014: 117-118). However, having said that, he was also very keen to avoid accusations of attempting 'a short cut by the means of such drugs as opium and hasheesh' (Fuller 1907: 305). It was, insists Regardie, 'never the intention of Crowley at any time, to use drugs as a substitute for the body-mind-discipline, which he insisted upon beyond all other things. This was the furthest notion from his mind' (Regardie 1994: 24; see also, Crowley 1994: 119). While we will see that the evidence suggests that it was not always the furthest notion from his mind, nevertheless, it is true that he at least claimed that he had 'no use for hashish save as a preliminary demonstration that there exists another world attainable-somehow' (Crowley 1994: 119). Ostensibly, his argument was that, 'since human nature is human nature after all, and since people tend to become discouraged and, from there, give up the struggle for enlightenment,' then, as Regardie insists, 'if they could be given some inkling of what the ineffable experience could be like, perhaps... they would be willing to overcome their own inertia and despondencyand work. It was the carrot to be waved in front of the donkey's nose. But waved only long enough to get the donkey started' (Regardie 1994: 24). 


\section{The trials and tribulations of the drug fiend}

Crowley's struggle with drugs is evident in the traces of ambivalence towards them in his work-which, of course, he shared with a number of other fin de siècle occultists and writers. There were a number of reasons for this ambivalence. Firstly, it is clear from his discussions of drug legislation, as well as a number of other comments scattered throughout his work, that he was conscious of the growing social concern about increasing drug use. As George Viereck, the editor of The International, put it in a revealing disclaimer at the beginning of his article on 'Cocaine,' 'we disagree with our contributing editor on some points,' noting that 'according to police statistics,' the drug 'is beginning to be a serious menace to our youth' (Viereck, in Crowley 1917b: 291). While they disagreed over some points, Crowley did not deny that this was a concern. Moreover, while psychoactives were associated with the creative and decadent culture of the fin de siècle, with artists, intellectuals, and the spiritual avant-garde, they quickly became identified with the uncultured, brutal world of the lower classes and 'youthful thrill-seekers' (Davenport-Hines 2002: 148-173). For example, Crowley observed that 'every other Chinese laundry is a distributing centre for cocaine, morphia, and heroin. Negroes and street peddlers also do a roaring trade. Some people figure that one in every five persons in Manhattan is addicted to one or other of these drugs' (1917b: 293). While he disputes the figures, nevertheless, he says, 'the craving for amusement is maniacal among this people who care so little for art, literature, or music, who have, in short, none of the resources that the folk of other nations, in their own cultivated minds, possess' (1917b: 293). This clearly bothered him, for it was not an area of society or a culture he wanted to be associated with.

Secondly, the use of drugs within esotericism was resisted as a profane shortcut by many within the occult milieu. For example, as Regardie notes, Mathers 'frowned upon all such methods, preferring the classical secret techniques of mind and spiritual training' (Regardie 1994: 9). Elsewhere, he makes the point that 'the Golden Dawn never recommended the use of any consciousness expanding drugs' (Regardie 2014: 127). Conscious of this, it was important to Crowley that his contemporaries understood his principal focus to be the development of techniques of transcendence rooted in the disciplined practice of magick, rather than intoxication. Again, Regardie 
insists that this 'fundamental premise was stated over and over again, in a hundred different ways.'

It was never that the drug experience per se could possibly replace the basic mental and spiritual discipline that he stood for, and which all previous occult teachers insisted upon... What was required beyond all other things was endurance and persistency-the discipline of the body-mind system, in the technical phases of the Work itself, to provide the basic necessary tools through which the mystical state would be reinstated, re-experienced, and re-explored (Regardie 1994: 25-26).

However, while this was true theoretically, in practice Crowley found the immediacy of induced experiences difficult to resist. For example, concerning the experience of astral projection, he recommends that it 'should be preceded by a (ceremonial) "loosening of the girders of the soul." ${ }^{6}$ How to do it is the great problem. I am inclined to believe in drugs' (Crowley 1910: 117). Hence, again, there is ambivalence towards the use of psychoactives in his work.

Finally, because his focus was on the development of 'the will,' he was highly critical of those whose pursuit of the 'True Will' had been compromised. He was adamant that 'only weaklings fell victim to a drug' (Sutin 2000: 277). This, of course, meant that his own experience of 'the restless wretchedness of a morphineuse deprived of the drug' (Crowley 1970: 252) was a deeply humiliating one. Therefore, there were times when, like most addicts, he simply denied that he had a problem and insisted to his followers that drugs had no power over him. Indeed, to an extent he believed this and, because he did, struggled with the brutal reality of addiction. For example, he argued that 'there are three main classes of men and women: (1) Afraid to experiment with anything... (2) Enslaved by anything that appeals to them. (3) Able to use anything without damaging themselves.' He, of course, claimed to belong to the final category, even insisting that, in the service of science, he had attempted to induce addiction through persistent use, but failed, such was the strength of his will: 'I attempted to produce a "drug-habit" in myself. In vain... I was always able to abandon the drug without a pang' (Crowley 1922a: 573). This, of course, is nonsense-and, indeed, frequently repeated nonsense. The truth is 
that his addiction had an increasingly detrimental impact on his life and work. 'There is no harm,' he argued, 'in man's experimenting with opium-smoking, but the moment he ceases to examine, to act from habit without reflection, he is in trouble' (Crowley 2000: 115). This comment arose out of his own experience of 'trouble,' his own inability to overcome acting from habit. For example, during his time at the Abbey of Thelema-the temple and spiritual training centre that he had established in Cefalù, Italy-he 'bought drugs from a Palermo pusher named Amatore and made them available to all residents' (Kaczynski 2010: 361). This led to problems. Although Richard Kaczynski claims that his stated goal was 'not to encourage drugs, but to make them so readily accessible that he removed all temptation' (2010: 361) in actual fact, as John Symonds comments, 'his over-indulgence in heroin and cocaine had an adverse effect on the... Abbey's discipline' (Symonds 1958: 76; see also Symonds 1971: 236-238, 245). Hence, in 1922, he left the Abbey for a period of rehabilitation in Fontainebleau. Again, he struggled, but failed. Some indication of the nature of this struggle is provided in a diary entry he wrote at this time:

I, Baphomet 666, wishing to prove the strength of my will and the degree of my courage have poisoned myself for the last two years and have succeeded finally in reaching a degree of intoxication such that withdrawal of the drugs (heroin \& cocaine) produce a terrible attack of the 'Storm Fiend.' The acute symptoms arise suddenly, usually on waking up from a nap.... Medium dose Heroin. This was a real indulgence in the worst sense of the word. It has occurred very frequently that I have taken a dose for reasons at present utterly unfathomable. (This is a confession indeed, for me, who claims to be the foremost living psychologist!) There is not the slightest discomfort to be removed, or the faintest wish to reach some still superior state. It is an absolutely perverse impulse.... There has been a constantly increasing indifference to matters of ordinary health, cleanliness and vanity. I seem hardly to know what the state of affairs is, as to defecation, etc.... There are numerous very alarming mental symptoms, but all really reduce to one only, the feeling that nothing is worthwhile. It is a sort of 'philosophical laziness' .... There is a dull malaise, combined lack of any interest in anything and the knowledge that cocaine would put me right at once. Cocaine is barred altogether of course. The reason is this: The hunger for it is strictly moral and a man ought to 
be able to master his moral passions. Physical torture, on the other hand, simply throws the moral apparatus out of gear; one cannot be blamed for committing suicide or doing any other foolish act when the pain is so strong as to prevent the manifestation of the Will altogether... Only cocaine could help me and I won't take it... Medium dose. My feeling is that the safest course is to arrange a mild jag; sufficient to overcome my general lassitude, which is beginning to make me open to violent suggestion to throw the whole cure overboard (Crowley 1921; see also Symonds 1971: 274-283).

Again, unlike hashish and peyote, because he had 'not much to thank' heroin and cocaine for, he was disturbed that he could not resist them: 'it is for these and these only that I hanker' (Crowley 1921). 'Heroin was,' as Symonds recalls, 'essential to his existence. He needed, too, rather a lot of heroin owing to his body's toleration: seven or eight or more grains a day, a phenomenal amount really if one considers that the usual dose is one-sixteenth or one-eighth of a grain. More than once I had steadied him while he injected himself in the armpit' (1958: 51). It is hardly surprising therefore that, in desperation, he 'wrote to Dr. Edward Cros... telling him the whole story' and requesting that he 'call and fix a sanatorium.' However, he added that he intended to 'direct [his] own treatment' (Crowley 1921). Why? Because, again, as the prophet of Thelema, despite the severity of his addiction, he did not believe that he needed medical assistance: "To submit to medical treatment would be to destroy my whole theory and blaspheme the Gods whose chosen minister I am!' (Crowley 1921) Predictably, he failed and, again, must've struggled enormously as a result, in that his addiction placed a question mark against his Thelemic teaching and personal authority. Indeed, many of Crowley's ostensibly objective comments about the relationship between addiction and the will can be understood as oblique references to his own torment: 'to possess the supply of a drug,' is to be 'the master, body and soul, of any person who needs it. People do not understand that a drug, to its slave, is more valuable than gold or diamonds' (Crowley 1917: 294b). Hence, while, on the one hand, he was fascinated by the power of drugs to stimulate the imagination and to produce ecstatic states-to 'rise to the cloudless and passionless bliss of the philosopher,' to 'behold the fantastic glories of fable, and those a thousandfold,' and to 'perceive the heart of Beauty in every vulgar and 
familiar thing' (Crowley 1916)—on the other hand, they eroded the power of the will, which was so central to his thought.

For much of the latter half of his life, drugs haunted and enslaved him. While it has been argued that he eventually managed to free himself from heroin in 1924 (see, Kaczynski 2009: 29-30), it has to be acknowledged that, even if he did, by 1940 he had succumbed to it again, continuing to use it until his death in 1947. Certainly, whatever the truth of Crowley's private habit, it would be naïve to believe that he entirely escaped his longing for heroine once it had found its way into his system. ${ }^{7}$ As William Burroughs put it, 'junk wins by default... If you have never been addicted, you can have no clear idea what it means to need junk with the addict's special need. You don't decide to be an addict. One morning you wake up sick and you're an addict... I have learned the junk equation... Junk is not a kick. It is a way of life' (1977: xv-xvi). Crowley understood this and we misunderstand him if we do not. Like Burroughs, he was clear that, 'a man who has once experienced the drug-life finds it difficult to put up with the inanity of normal existence. He has become wise with the wisdom of despair' (Crowley 1979: 353).

\section{High times with Allan Bennett}

The 'drug-life' began for Crowley when he was introduced to the esoteric significance of psychoactives by his friend, mentor, and fellow member of the Golden Dawn, Allan Bennett. Although it should be noted that George Cecil Jones, who had first introduced Crowley to the Golden Dawn and encouraged his interest in the occult, was an industrial chemist with a knowledge of pharmaceuticals, it was almost certainly Bennett, who was also a chemist by training, who introduced them into his life as technologies that might be useful for the practice of magic. While Bennett could have, like Jones, led a materially comfortable life, his commitment to occultism and then Buddhism, as well as chronic asthma, led to frequent periods of poverty. Indeed, as with many in the nineteenth century, it was the medication prescribed to alleviate his suffering that revealed to him the spiritual potential of drugs (see, Sutin 2000: 65). As Crowley commented, 'his cycle of life was to take opium for about a month,' then 'when the effect wore off... he had to inject morphine. After a month of this he switched to cocaine, which he took until he began to see "things" and was then reduced to chloroform' (quoted in Sutin 2000: 65). As Bennett's life became increasingly organized around periods of intoxication, so he 
became convinced that 'there exists a drug whose use will open the gates of the World behind the Veil of Matter' (Bennett, quoted in Regardie 2014: 117). Crowley was so impressed by his thesis, that once Bennett had 'imparted to him the rudiments of his pharmacological knowledge' (Regardie 2014: 117), he began in earnest experimenting with opium, cocaine, ether and hashish in an attempt to gain access 'behind the veil of the universe' where 'live the mystic and the true artist' (Crowley 1994: 121). (Such substances were, of course, all legally available in Britain until the passing of the Dangerous Drugs Act in 1920.) Together, says Crowley, he and Bennett, 'for many months... studied and practiced Ceremonial Magic, and ransacked the ancient books and MSS of the reputed sages for a key to the great mysteries of life and death.' He continues:

Through the ages we found this one constant story. Stripped of its local and chronological accidents, it usually came to this-the writer would tell of a young man, a seeker after Hidden Wisdom, who, in one circumstance or another, meets an adept; who, after sundry ordeals, obtains from the said adept, for good or ill, a certain mysterious drug or potion, with the result (at least) of opening the gate of the Other-world. This potion was identified with the Elixir Vitae of the physical Alchemists, or one of their 'Tinctures,' most likely the 'White Tincture' which transforms the base metal (normal perception of life) to silver (poetic conception)... (Crowley 1994: 98; cf., Symonds 1958: 106-107)

Crowley would later bemoan the project as a series of 'fruitless attempts to poison ourselves with every drug in (and out of) the Pharmacopœia,' because, 'like Huckleberry Finn's prayer, nuffin' come of it' (Crowley 1994: 98). This, again, reflects the ambivalence in Crowley's work. It was, however, disingenuous. It is clear that his experiments with Bennett, who he referred to as 'a flawless genius' (Crowley, quoted in Kaczynski 2009: 64) were important to him and informed his thinking about drugs. Indeed, far from nuffin' coming of it, as we have seen, a great deal came of it.

\section{This holy herb}

This is the Profit of mine Intoxication of this holy Herb, The Grass of the Arabs, that it hath shewed me this Mystery (with many others), not as a New Light, for I 
had that aforetime, but by its swift Synthesis and Manifestation of a long Sequence of Events in a Moment (Crowley 1974: 127).

An ardent admirer of Richard Burton, the Victorian Orientalist, travel writer, and translator of the Arabian Nights, in 1903, Crowley, with his new wife Rose Kelly, began his own journey to the Orient. During these and subsequent travels, not only did he betray the influence of Burton's interests and idiosyncrasies (see, Sutin 2000: 35, 51), but, he claims that, in at least one respect, he went beyond the great man 'who solved nigh every other riddle of the Eastern Sphinx' (Crowley 1994: 95). Whereas Burton used hashish and regarded it as 'no more than a vice' (1994: 96), he discovered its true significance. In India, for example, he relates how he was taught 'systems of meditation' in which 'lesser Yogis employed hashish... to obtain Samadhi, that oneness with the Universe...' (1994: 98). Moreover, while this was no doubt true, arguably more significant was what he was reading during this period: 'I also had the advantage of falling across Ludlow's book, and was struck by the circumstance that he, obviously ignorant of Vendantist and Yogic doctrines, yet approximately expressed them, though in a degraded and distorted form' (1994: 98-99). In other words, not only does he claim that hashish was used to attain states of transcendence that were normally the result of disciplined meditation, but also that accounts of cannabis intoxication in the West come very close to describing the experiences of mystics in the East. Nevertheless, he is careful to insist that hashish should be used as a tool along with 'discipline and training in the meditative arts' (Regardie 1994: 20). That said, although we have noted Regardie's argument that he understood hashish primarily as an initial introduction to mystical experience, he does concede that Crowley taught users to 'expect far better results with its use than if the tool of meditation alone was used, and vice versa' (Regardie 1994: 20). Indeed, 'there might be occasions, even when one had acquired supreme skill in mediation, when an additional fillip or stimulus provided by judicious and temperate use of hashish would enable one to surmount the sterility and grimness of the long-protracted discipline, to soar exaltedly above the armored restriction of the ego-functions into the ineffable' (Regardie 1994: 26-27). As such, cannabis, 'the grass of the Arabs,' can be considered a 'Holy herb... which might be appointed for... Enlightenment' (Crowley 1974: 124, 127). Hence, again, he insists that, while some might accuse him of 'pure sloth or weariness' (Crowley 1994: 95) of laziness in occult 
practice, in fact he used hashish as a technology to 'loosen the girders of the soul' (Crowley 1994: 100; see also, Fuller 1907: 305). Indeed, in 1907, in an analysis of Crowley's philosophy (which is actually more of an erudite exercise in ingratiation), John F.C. Fuller claims that this was indeed the case: 'hasheesh may in some way be the loosener of the girders of the soul, but this is all' (Fuller 1907: 305). However, that this was all it was for Crowley is doubtful. In the final analysis, it is difficult to avoid the conclusion that Crowley found in cannabis a shortcut to transcendence, which, regardless of his emphasis on the importance of skill, knowledge, and sober ritual, he was never quite able to leave behind. Hence, it is unsurprising to discover that, not only did he struggle to meditate, but that he found psychoactives to be a significant help in realizing his spiritual goals.

I was aware of the prime agony of meditation, the 'dryness'... which hardens and sterilizes the soul. The very practice which should flood it with light leads only to darkness more terrible than death... Meditation therefore annoyed me, as tightening and constricting the soul. I began to ask myself if the 'dryness' was an essential part of the process. If by some means I could shake its catafalque of Mind, might not the Infinite Divine Spirit leap unfettered to the Light? Who shall roll away the stone? (Crowley 1994: 99)

The answer, of course, was the 'burning daughter of the Jinn'-hashish (Crowley 1994: 95).

Its perhaps worth noting that of some significance in his experience of hashish was the perception of transcending of space and time. Spatiotemporal transcendence, which is so common in psychedelic history, invests intoxication with an otherworldly significance. As he notes in his magnum opus, Magick: Liber ABA, Book 4, hashish enables us to understand that 'Time and Space are forms by which we obtain (distorted) images of Ideas. Our measures of Time and Space are crude conventions, and differ widely for different Beings' (2000: 501). The point is that, as both Ludlow and Baudelaire had discussed, hashish intoxication 'involveth the Mystery of the Transcending of Time, so that in One Hour of our Terrestial Measure did I gather the Harvest of an Aeon, and in Ten Lives I could not declare it' (Crowley 1974: 124). 


\section{The elixir}

While he is often regarded as having 'experimented with more drugs more frequently than anybody in the West before the Neurological Revolution of the 1960s' (Wilson 2014: xxiii; see also, Wilson 2000), and although he became addicted to cocaine and heroin, his preferred technology of transcendence was peyote. At the turn of the twentieth century, it was known as anhalonium lewinii, a term that acknowledges the groundbreaking research of Louis Lewin, the German pharmacologist who, in 1888, published the first scientific report on the psychoactive properties of the cactus. ${ }^{8}$ His work led to much interest in peyote and eventually to the isolation of mescaline by Arthur Heffter in 1897 and its synthesis by Ernst Späth in 1919. Crowley's interest, therefore, was part of a growing fascination with peyote in Europe and America. Indeed, bearing in mind that Bennett would almost certainly have known of it, it is likely that Crowley first heard of it during his time in the Golden Dawn. Nevertheless, he soon familiarised himself with the available research and even made a trip to Park, Davis and Co., the American company that had originally secured samples of the cactus: 'Parke Davis were charming and showed me over their wonderful chemical works... They were kind enough to interest themselves in my researches in Anhalonium Lewinii and made me some special preparations on the lines indicated by my experience which proved greatly superior to previous preparations' (Crowley 1989: 768). Although he makes surprisingly few references to the drug-sometimes simply referring to it in code as ' 31 '9 - there is little doubt that it was a significant part of his work for several years. Indeed, he indicated that he intended to publish a study of the effects of peyote in The Equinox, entitled 'Liber 934: The Cactus.' It would be 'an elaborate study of the psychological effects produced by Anhalonium lewinii (Mescal buttons), compiled from the actual records of some hundreds of experiments; with an explanatory essay' (Crowley 1919: 16). Although it was never published and probably never written, it does indicate his fascination with the drug. This is supported by a marginal note against 'anhalonium lewinii' that Crowley scribbled in the Abbey of Thelema's library copy of Diary of a Drug Fiend: 'I made many experiments on people with this drug in 1910, and subsequent years' (Crowley 1971: 236). This claim was subsequently repeated to the botanist Arthur Bernhard-Smith. In a short note Bernhard-Smith published in the British Medical Journal, he recalls that he had 'carried out a series of personal 
experiments, in conjunction with Dr. Havelock Ellis, on the effects of the reputed deliriant mescal (Anhalonium lewinii), making use of a strong infusion of seeds or "buttons" of the plant.' He then notes that, 'acting on the advice of a literary acquaintance, a latter-day magician well-known in the West End of the London, who claims to have administered this form of the drug to hundreds of his clients, I proceeded to a dose...' (Bernhard-Smith 1913: 21). The magician, of course, was almost certainly Crowley. Again, in 1913 Crowley commented that the results of peyote intoxication 'have not as yet been thoroughly studied.' However, he continues 'it is my immediate purpose to repair this neglect' (Crowley 1913: 37). Of course, it hardly needs mentioning that frequently taking a psychoactive substance and making a thorough study of it are two very different activities. If they are not, then Crowley certainly seems to have made a thoroughly study, in that besides regularly using the drug himself, he managed to intoxicate numerous people at his anhalonium parties (see, for example, Kaczynski 2010: 315). At one of these psychedelic esoteric soirees he even introduced the drug to the celebrated author Katherine Mansfield (see, Sutin 2000: 229-230) and at another in New York to Theodore Dreiser (see, Sutin 2000: 253). Such was his growing relationship with peyote, that he began referring to it as 'the elixir introduced by me to Europe' (Crowley 1913: 37)—which, of course, was not true.

The fact that he referred to it as an 'elixir' is significant, in that it located it firmly within the tradition of esotericism as a visionary and alchemical technology that could be employed during rituals. Likewise, he also refers to it as a 'libation.' For example, during a performance of his theatrical 'Rites of Eleusis,' which were comprised of seven invocations, a 'Cup of Libation' was passed around his audience. Indeed, he recalled that the very idea of performing 'rites' came to him during a summer spent taking peyote and developing rituals with Commander Guy Montagu Marston:

Marston and I started with the evocation of Bartzabel, suggested by a talk while I was staying with him at his house, Rempstone, Dorset. The idea of general 'rites' developed during this summer from casual rituals adopted during the Anhalonium experiment. When LW [Leila Waddell] and I played and read poetry against each other before the Lord, we got such wonderful spiritual results that we tried to reduce all to a rule (Crowley 1998: 259). 
The Rites of Eleusis presented the ideal occasion for a psychedelic happening, in that they were intended, as Sutin notes, 'to unite the performers and the audience in an ecstasy that would, as had the mysteries of ancient Eleusis, reveal the divine capacities of the awakened human soul' (Sutin 2000: 209). In the event, the Rites actually had little to do with the ancient ceremonies of Eleusinian Mysteries-which have been linked with the ritual use of psychoactives. Crowley read poetry, Waddell played violin, and Victor Benjamin Neuburg danced as the intoxicated audience gradually slipped into an enchanted world. At one early performance of the 'Rite of Luna' at Crowley's London flat at 124 Victoria Street, we are told that the 'Cup of Libation' was 'a potent liquid mixture consisting of alcohol, fruit juices, possibly some type of opium derivative, and most certainly an infusion of... peyote' (Sutin 2000: 210). Raymond Radclyffe, a reporter for the Daily Sketch, who attended one of the ceremonies, recorded the following:

The Master of Ceremonies... ordered a brother to 'bear the Cup of Libation.' The brother went around the room, offering each a large golden bowl full of some pleasant-smelling drink. We drank in turn. This over, a stalwart brother strode into the centre and proclaimed 'The Twelvefold Certitude of God.' Artemis was then invoked by a greater ritual of the Hexagram. More Libation. Aleister Crowley read us the Song of Orpheus from the Argonauts. Following this song we drank our third Libation, and then the bothers led us into the room... By this time the ceremony had grown weird and impressive, and its influence was increased when the poet recited in solemn and reverent voice Swinburne's glorious first chorus from 'Atlanta'... Again a Libation; again an invocation to Artemis.

Following more poetry, Neuburg's dance, and Waddell's music, he records that, intoxicated, 'we were thrilled to our very bones' and that 'most of us experienced the Ecstasy which Crowley so earnestly seeks.' It was he records, 'a really beautiful ceremony-beautifully conceived and beautifully carried out' (Radclyffe, quoted in Booth 2000: 286-288).

\section{The ceremonial use of drugs}


Crowley's use of drugs within ritual contexts was, of course, not novel. As noted above, it can be traced back to his experiments with Bennett. Indeed, Symonds makes an interesting observation concerning a comment in one of Bennett's notebooks, dated 1899-when he was living with Crowley in his flat on Chancery Lane. He notes that he had begun to use cocaine during ceremonies for 'the evoking of gods and the conjuring up of demons,' because 'it doubtless helped the materialisations' (Symonds 1958: 105106). With such ideas in mind, it is interesting to read the following in Liber AL vel Legis (The Book of the Law), which he claimed to have been dictated to him by a incorporeal entity he referred to as Aiwass: 'I am the Snake that giveth Knowledge \& Delight and bright glory, and stir the hearts of men with drunkenness. To worship me take wine and strange drugs whereof I will tell my prophet, \& be drunk thereof! They shall not harm ye at all' (Crowley 1976: 31). Again, Symonds notes that, while a sex rite was often used as an introduction to the 'Alamantrah Working' - the aim of which was to summon and communicate with an entity called Alamantrah-when this failed, drugs were taken, 'usually anhalonium, but sometimes opium or hashish' (Symonds 1958: 177-178; see also, Symonds 1971: 216). There is, in other words, an overlap between Bennett's use of intoxication in liturgical contexts and Crowley's use.

Similarly, there is also evidence that he used hashish in his 'Augoeides invocations.' The relatively obscure Neoplatonic term, $\alpha \cup \gamma o \varepsilon เ \delta \eta \varsigma$ - which refers to luminosity-appears infrequently in modern occultism. Crowley almost certainly lifted it from Edward Bulwer Lytton's Rosicrucian novel Zanoni, in which it is discussed in a technical footnote on the 'mystical Platonists'- 'Lytton calls him Adonai in "Zanoni," and I often use this name in the note-books' (Crowley 1909: 159; cf. Lytton 1861: 130). Lytton's novel, which relates the story of Zanoni and Mejnour, the two last survivors of an ancient sect, describes them as seers who have managed to transcend time, freeing themselves from earthly passions, and being unaffected by the ravages of death and decay. They were able to do this because they had found a way of living continually in the realm of the spirit, an advanced state that only the most accomplished mystics can hope to achieve. While the path to this state is extraordinarily difficult, requiring absolute devotion in order to survive the daunting trials of mind and body, Lytton also suggested that the answer might be found in a 'golden elixir' that 'some of the alchemists enjoyed' (Lytton 1861: 139). The suggestion of an 'immortal elixir,' an 'elixir 
that baffles death' (Lytton 1861: 31, 101) which, moreover, enables a person to invoke spiritual entities (as Bennett had claimed), was certainly of interest to Crowley. Also of interest to him was the notion of Augoeides as the individual 'sphere of the soul,' which says Lytton, 'is luminous when nothing external has contact with the soul itself; but when lit by its own light, it sees the truth of all things and the truth centred in itself' (Lytton 1861: 130). Although, at times, Crowley understood the Augoeides invocation in terms of communion with a distinct spiritual entity, his Holy Guardian Angel, at other times he used it to refer to his 'Higher Self'/'Genius' (concepts which were common in Theosophy). Furthermore, as Marco Pasi comments, 'the ritual of the Augoeides is interesting because it took place almost exclusively in an imagined ritual space' (Pasi 2012: 73)—which, of course, he understood drugs to be peculiarly effective in evoking.

It is worth noting, moreover, that the Augoeides invocation formed part of the 'Abramelin Operation' as set out in The Book of the Sacred Magic of Abramelin the Mage - a translation by Mathers of an esoteric German grimoire, which had been translated into French, and which he had discovered in the Bibliothèque de l'Arsenal in Paris. The text, which, interestingly, Mathers notes was known to Bulwer Lytton and Éliphas Lévi, included its own founding myth, which identified it as the magical system of Abramelin/Abra-Melin, an Egyptian mage, who passed on his knowledge to Abraham von Worms, a medieval Jewish scholar. Essentially, the ritual consists of a series of laborious and elaborate preparations, undertaken over a long period of time, the aim of which is to obtain the 'knowledge and conversation' of one's 'Holy Guardian Angel.' Having performed the ritual in inner space, Crowley claimed that he had managed to achieve the same result as if he had performed it physically, namely 'Knowledge and Conversation of the Holy Guardian Angel.' It was, as Pasi says, subsequently 'perceived by him as one of the most important magical achievements of his entire life' (Pasi 2012: 73). The point here is that, in his discussion of the significance of hashish, he mentions an experience of 'what Abramelin the Mage calls the Knowledge and Conversation of the Holy Guardian Angel, another (and less metaphysically pretentious) way of speaking of the "Higher Self" or "Genius"' (Crowley 1994: 133). Again, speaking of 'that supreme state in which the man has built himself up into God' (Crowley 1994: 141-142), 'the final and perfect identity of the Self with the Holy Guardian Angel,' he notes that, while 'one may doubt whether the drug alone ever does this,' there are those for whom hashish 
can be an important instrument in the ritual: 'it is perhaps only the destined adept who, momentarily freed by the dissolving action of the drug from the chain of the four lower Skandhas, obtains this knowledge which is his by right, totally inept as he may be to do so by any ordinary methods' (Crowley 1994: 142). While there is necessarily some speculation in the above discussion, what is clear is that, influenced by Bennett, Zanoni, and The Book of the Sacred Magic of Abramelin the Mage, as well as by his reading of Ludlow and Baudelaire, he used drug induced altered states to 'loosen the girders of the soul' within ritual contexts.

\section{Crowley and the psychedelic revolution}

Regardie's discussion of Crowley's use of hashish needs to be understood as part of a broader Crowleyan apology. ${ }^{10}$ More specifically, while it betrays a slightly more restrained attitude to drug use than that of his mentor and a preference for ceremonial work far closer to the teaching of the Golden Dawn, it is worth noting that his essay was written in 1968. Regardie got to know Timothy Leary and developed a relationship that, as Gerald Suster notes, 'stimulated his productivity' (1989: 142). While deploring the undisciplined use of psychoactives and indeed Crowley's own addiction to heroin and cocaine, he began to appreciate 'the use of mind-expanding drugs for willed magical and mystical purposes' (Suster 1989: 143). He argued that 'drugs are just tools for the exploration and enhancement of consciousness.' Each drug, he insisted, 'should be employed for a specific purpose and used with intelligence and will' (Suster 1989: 143). Hence, although he quite correctly rejected the idea of 'Crowley as a Victorian hippie' (Suster 1989: 142), nevertheless, in an effort to reintroduce his work to a new generation of seekers, he sought to demonstrate its relevance to contemporary psychedelia by explicitly drawing parallels between 'The Psychology of Hashish' and the ideas articulated by Maslow, Huxley, Robert de Ropp, David Solomon, Alan Watts, and particularly Leary (see, Regardie 1994: 39). Indeed, he commended 'wholeheartedly' The Psychedelic Experience by Leary, Ralph Metzner, and Richard Alpert, as 'the only single text which approximates, albeit distantly, the hashish essays of Crowley.' Moreover, he says that, 'were Crowley alive today and familiar with this work, I am altogether confident that he would have immediately written a "rave" review of it in one of his Equinox publications' (Regardie 1994: 40). Again, he claimed that, not only would Crowley have greeted LSD as 'the drug of choice, the ideal chemical instrument he had 
yearned for as the experimental aid to the magico-mystical system he had developed' (Regardie 1994: 25), but also that Huxley, Watts and Leary in their own discussions of the drug were essentially following a trajectory initiated by him in the early years of the twentieth century. Indeed, possibly influenced by Regardie, the British occultist Kenneth Grant even argued that Leary 'identified himself so entirely with the current initiated by Crowley... that he considers one of his aims to be the completion of the work of preparing the world for cosmic consciousness, which Crowley had begun' (quoted in Suster 1989: 142). Regardie, however, went further, insisting that Huxley's argument that psychedelics can be used 'to potentiate the non-verbal education of adolescents and to remind adults that the real world is very different from the misshapen universe they have created for themselves by means of their culture conditioned prejudices,' reflects the principal tenets of Crowley's philosophy; Watts' conviction that there is 'no essential difference between the experiences induced, under favorable conditions, by... chemicals and the states of "cosmic consciousness" recorded by R.M. Bucke, William James, Evelyn Underhill, Raynor Johnson and other investigators of mysticism...' concurs with the findings of Crowley's own research; Leary's assertion that 'the most effective way to cut through the game structure of Western life is the use of... consciousness-expanding drugs...' goes some way towards Crowley's own conclusions (Regardie 1994: 38-39). However, as far as Regardie is concerned, while there are significant lines of continuity between their attempts to dislocate a person's sense of reality, Crowley 'had the edge over most of our present-day researchers' (Regardie 1994: 41) because he incorporated drug-induced transcendence into an occult system. This, he believes, was Crowley's genius from which the new generation of psychedelic explorers needs to learn (see Suster 1989: 140-144).

Concerning the idea of Crowley as father of the psychedelic revolution, it is sometimes claimed that, in October, 1930, during his time in Berlin, he 'gave mescal to, amongst others, the youthful Aldous Huxley' (King 2013: 138). James Webb even claims that there is 'first hand evidence' provided by 'a former disciple of Crowley' (1976: 439, 482; see also, Churton 2014: 171-172). This would, of course, be significant, in that it would establish a very clear historical link between Crowley and the psychedelic counterculture. Unfortunately, it is hampered by a comprehensive lack of evidence. There is little doubt that the two briefly met during the evening of October 4 at the 
Müncher Hofbrau, but there is no evidence that they took mescaline together or that it was even a topic of conversation. Indeed, not only does Huxley never mention the encounter with Crowley, but there is not the slightest suggestion of him ever having taken the drug prior to 1953, when he declared to Humphry Osmond, 'I am eager to make the experiment and would feel particularly happy to do so under the supervision of an experienced investigator like yourself' (Huxley, quoted in Murray 2003: 399). 'Thus,' he recalls, 'it came about that, one bright May morning, I swallowed four-tenths of a gramme of mescaline dissolved in half a glass of water and sat down to wait for the results' (Huxley 1994: 3). There can be no doubt that he had never taken it before. As his relative, Siggy Wessberg, has stated: 'In May 1953, following correspondence with Canadian psychiatrist Humphry Osmond, then visiting Los Angeles, Aldous Huxley took mescaline for the first time' (quoted in Dunaway 1995: 93-94). Again, not only is there no evidence in Huxley's corpus that Crowley had any impact on his thought, but his friend, Sybille Bedford, in her authoritative and detailed biography, lists those who had experimented with mescaline since Lewin and prior to Huxley, but makes no mention of Crowley (Bedford 1974: 143). We all meet people in the course of our lives, some of whom have a profound impact on the way we view the world, some whom have no impact at all, and most of whom have an indiscernible influence somewhere in-between. Wherever Crowley stood in Huxley's world, he seems not have made much of an impression at all.

Nevertheless, Regardie's view of him as the father of modern psychedelia became increasingly popular within Western occulture. Indeed, it is often simply assumed that, as Francis King insists, 'most... occultists who have taken a favourable attitude toward the use of consciousness-altering drugs have been influenced by Aleister Crowley' (King 2013: 138). Similarly, Don Webb, former high priest of the Temple of Set, is clear that Crowley introduced drugs to the West as a method of self-transformation (2013: 5). Likewise, Kaczynski portrays Crowley as a psychedelic trailblazer: 'Half a century before Timothy Leary told the flower children to "Tune in, turn on, drop out," AC had experimented with drugs as an adjunct of consciousness expansion' (2010: 562). Again, William Breeze of the Ordo Templi Orientis has argued that Crowley was 'a pioneer in the use of entheogens,' that his short story 'The Drug' (1909), 'stands as one of the first-if not the first-accounts of a psychedelic experience,' and that he fostered the 
use of drugs 'in literary and occult circles in Europe and America' (2015: xi, xiii). Indeed, Booth suggests that he should be placed 'at least equal to Aldous Huxley as a writer and chronicler of the part drugs play in visionary experience,' and that, had he not 'developed such a notorious reputation, he would surely have been as seriously considered in due course as Huxley was after the publication of The Doors of Perception and Heaven and Hell' (2000: 336).

While such assessments are, of course, not entirely wide of the mark, in that Crowley was an important psychedelic thinker who has not received the recognition he deserves, nevertheless, they do tend to overstate his significance. Firstly, not only was creative drug use hardly a novel practice within literary and occult circles, but both Baudelaire's 'The Poem of Hashish' (originally published in 1850) and Ludlow's The Hasheesh Eater (originally published in 1857), both of which had a formative influence on Crowley's thought, predated his birth in 1875. Secondly, although it is important to recognize the significance of the link Crowley developed between psychoactives and ceremonial magic, there had already been some reflection on this relationship. LouisAlphonse Cahagnet, Paschal Beverly Randolph, Helena Blavatsky, Allan Bennett, W.B. Yeats, and Maude Gonne had all, in varying degrees, given the matter some attention. Moreover, there is evidence to suggest that, by the mid-1880s, the Hermetic Brotherhood of Luxor had already experimented with drugs during initiation ceremonies (see, Godwin, Chanel, Deveney 1995). Thirdly, his writing on drugs was arguably too outré, rhetorical, and unsystematic to have had the cultural impact of Huxley's far more concise and erudite discussions. Finally, a distinction needs to be made between Crowley's influence as a profane icon and his influence as an occult thinker. While the idea of Crowley found its way into the burgeoning occulture of the 1960s, there is a question concerning the extent to which his ideas had a formative influence on psychedelia. Certainly, the idea of Crowley-as a symbol of transgressionhad a cultural impact. Not only was his image used by Peter Blake in the artwork for The Beatles' psychedelic classic, Sgt. Pepper's Lonely Hearts Club Band (1967), but, in The Politics of Ecstasy, Leary encodes the idea of Crowley with psychedelic meaning by identifying him as one of Britain's 'inveterate trippers, heads, and stoned visionaries' (1970: 97), noting that 'he experimented with every available drug as a means of transcendence,' that he used peyote 'to turn on the audiences at his lectures,' and that 
he 'articulated the viewpoint that drug prohibition was not only useless but actually intensified the problem of drug abuse' (1990: 258). Andy Warhol even commented that the role of the counterculture in 'the evolution of society was similar to that of Alistair [sic] Crowley, the occult philosopher who scandalized the previous generation with his flamboyance and his libertarian ideas ("Do what thou wilt is the whole of the law")' (Leary 1990: 199). However, again, it was primarily the idea of Crowley as profane icon that appealed to the counterculture. There is relatively little evidence during the 1960s psychedelic revolution-beyond the occult milieu and those who had a particular interest in Crowley's philosophy, such as Jimmy Page of Led Zeppelin, the film director Kenneth Anger, and the writer Robert Anton Wilson-that much detail was known about his thought, let alone his ideas regarding the esoteric significance of intoxication. While Leary may have been an exception, again, there are only a few references and little evidence of any significant influence. This, of course, was not because the counterculture disagreed with his ideas, but rather because, as Suster says, during the 1960s his 'books... were expensive and as hard to locate as the work of a Russian dissident' (1989: 140). However, by the end of the decade, when the psychedelic counterculture was beginning to fade, a revival of the interest in the occult had started to gain ground, central to which was the republication of his works in affordable editions. That said, again, despite the efforts of Regardie, the focus tended not to be on his theories of intoxication. Even today, this is still a neglected area in the study of Crowley's thought.

\section{Concluding comments}

Crowley's importance in the history of psychedelic esotericism relates principally to the way in which he was able to distil a number of ideas circulating at the turn of the twentieth century. He possessed, in a way that few others did, an intellectual arrogance, ${ }^{11}$ a charismatic authority, and a penchant for transgression that enabled him to immerse himself in the occulture of the fin de siècle and to surface with an eclectic esoteric philosophy that inspired belief. Core themes of the period, such as those of decline and rebirth, and the Romantic notion of a New Age, were reimagined in terms of the passing of the Aeon of Osiris and the apocalyptic advent of the Aeon of Horuscharacterized by self-realization and self-actualization (Crowley 1976: 12-13). Again, if Max Nordau saw in Baudelaire 'at once a mystic and an erotomaniac' inspired by visions 
of 'hashish and opium' (1895: 285), Crowley was the epitome of that dark trajectory.

Crowley's articulation of an approach that used 'the method of science' to pursue 'the aim of religion' was of course a development of ideas already in circulation. Not only were similar approaches evident in the work of members of the Society for Psychical Research, but Crowley explicitly drew on Jamesian ideas concerning the psychological interrogation of mystical states. In particular, drugs emerged as technologies that enabled users to induce states of transcendence in a way that could be controlled and, therefore, examined. As such, they emerged as an important element in the reversal of the modern discourse that differentiated science and religion. Psychoactives were technologies that could be used to access other forms of consciousness and, perhaps, other levels of reality. Even if Crowley cannot be said to have had the cultural impact of Huxley, his occult theory and practice represents an important moment in psychedelic history.

Finally, because nineteenth century occultists who wanted to maintain a certain level of credibility, not to say respectability, needed to distance their ideas from discourses of madness and addiction, they tended express ambivalence toward drug use and even a preference for abstinence. Crowley, while not too worried about respectability, was nevertheless concerned about esoteric credibility. Consequently, several times he suggested that psychoactives should, in effect, be seen as training wheels on the novice's occult bicycle. He was also keen to advance the notion that psychedelic experimentation could be aligned with studies in the psychology of consciousness. Hence, for example, James's Varieties of Religious Experience provided a great service, in that it constructed a respectable scientific context within which to embed his accounts of induced altered states. However, regardless of his discussions of intoxication in occult practice, he was always careful to focus on the development of the unaided will. That said, in the final analysis, we have seen that his few typically candid autobiographical reflections reveal a man haunted by addiction.

\section{References}

Baudelaire, Charles. 1910. 'The Poem of Hashish,' The Equinox 1.3, 39-64.

Bedford, Sybille. 1974. Aldous Huxley: A Biography. Vol. 2, 1939-1963. London: Chatto \& Windus, 1974. 
Booth, Martin. 2000. A Magick Life: A Biography of Aleister Crowley. London: Hodder \& Stoughton.

Breeze, William. 2015. 'Introduction.' In Aleister Crowley, The Drug and Other Stories. Ware: Wordsworth Editions, 2015, xi-xviii.

Burroughs, William S. 1977. Junky. London: Penguin.

Churton, Tobias. 2014. Aleister Crowley: The Beast in Berlin. Art, Sex, and Magick in the Weimar Republic. Rochester: Inner Traditions.

Crowley, Aleister. 1909a. 'The Temple of Solomon the King (Book 1),' The Equinox 1.1, 141-230.

Crowley, Aleister. 1909b. 'The Drug,' The Idler 34, No. 36 (January), 403-408. Reprinted in Aleister Crowley, The Drug and Other Stories. Ware: Wordsworth Editions, 2015, 107113.

Crowley, Aleister. 1910. 'The Temple of Solomon the King (Book 4),' The Equinox 1.4, 43-118.

Crowley, Aleister. 1913. 'Energized Enthusiasm: A Note On Theurgy,' The Equinox 1.9, 17-46.

Crowley, Aleister. 1916. 'The Attainment of Happiness,' Vanity Fair (November): https://www.100thmonkeypress.com/biblio/acrowley/periodicals/attainment/attain ment.pdf (accessed July 7, 2016).

Crowley, Aleister. 1917a. 'Absinthe-The Green Goddess,' The International (February), 47-51.

Crowley, Aleister. 1917b. 'Cocaine,' The International (October), 291-294.

Crowley, Aleister. 1919. 'A $\therefore$ A $\therefore$ Præmonstrance,' The Equinox 3.1, 11-17.

Crowley, Aleister. 1921. 'Liber XVIII: The Fountain of Hyacinth':

http://hermetic.com/crowley/libers/lib93.html (accessed July 4, 2016).

Crowley, Aleister (writing under the pseudonym 'A New York Specialist'). 1922a. 'The Great Drug Delusion,' The English Review (June), 571-576

Crowley, Aleister (published under the pseudonym 'A London Physician'). 1922b. 'The Drug Panic,' The English Review (July), 65-70.

Crowley, Aleister. 1923. 'Ethyl Oxide': http://lib.oto-usa.org/crowley/essays/ethyloxide.html (accessed 27 June, 2016).

Crowley, Aleister. 1970. Moonchild. York Beach: Samuel Weiser. 
Crowley, Aleister. 1974. The Book of Thoth. York Beach: Weiser.

Crowley, Aleister. 1976. The Book of the Law. York Beach: Red Wheel/Weiser.

Crowley, Aleister. 1979. Diary of a Drug Fiend. London: Abacus.

Crowley, Aleister. 1989. The Confessions of Aleister Crowley. Edited by John Symonds \& Kenneth Grant. London: Arkana, 1989.

Crowley, Aleister (writing under the pseudonym Oliver Haddo). 1994. 'The Psychology of Hashish.' In Israel Regardie and Aleister Crowley, Roll Away the Stone: An Introduction to Aleister Crowley's Essays on the Psychology of Hashish, with the Complete Text of Aleister Crowley's The Herb Dangerous. North Hollywood: Newcastle Publishing, 93-152. Originally published in The Equinox 1.2 (1909), 31-89.

Crowley, Aleister. 1996. Magical Diaries of Aleister Crowley: Tunisia 1923. Edited by Stephen Skinner. York Beach: Weiser.

Crowley, Aleister. 1998. The Vision and Voice, with Commentary and Other Papers. Boston: Red Wheel/Weiser.

Crowley, Aleister. 2000. Magick: Liber ABA, Book 4. York Beach: Samuel Weiser.

Davenport-Hines, Richard. 2002. The Pursuit of Oblivion: A Social History of Drugs. London: Phoenix Press.

Dunaway, David King. 1995. Aldous Huxley Recollected: An Oral History. New York: Carroll \& Graf.

Frank, Priscilla. 2014. 'Meet Cameron, The Countercultural Icon Who Bewitched Los Angeles,' The Huffington Post (August 8): http://www.huffingtonpost.com/2014/08/08/marjorie-cameronmoca_n_5656561.html (accessed July 6, 2016).

Fuller, John F.C. 1907. The Star in the West: A Critical Essay Upon the Works of Aleister Crowley. London: Walter Scott Publishing Co.

Godwin, Joscelyn, Christian Chanel, and John Patrick Deveney. 1995. The Hermetic Brotherhood of Luxor: Initiatic and Historical Documents of an Order of Practical Occultism. York Beach: Samuel Weiser.

Huysmans, Joris-Karl. 1959. Against Nature. Trans. by Robert Baldick. Harmondsworth: Penguin.

Huxley, Aldous. 1994. The Doors of Perception and Heaven and Hell. London: Flamingo.

Kaczynski, Richard. 2009. The Weiser Concise Guide to Aleister Crowley. San Francisco: Weiser. 
Kaczynski, Richard. 2010. Perdurabo: The Life of Aleister Crowley. Berkeley: North Atlantic Books, 2010.

King, Francis. 2013. Tantra for Westerners: A Practical Guide to the Way of Action, second edition. Oxford: Mandrake.

Leary, Timothy. 1970. The Politics of Ecstasy. London: Paladin, 1970.

T Leary, Timothy. 1990. Flashbacks: A Personal and Cultural History of an Era. An Autobiography. New York: Tarcher/Putnam.

Lewin, Louis. 1888. 'Ueber Anhalonium Lewinii,' Archiv für experimentelle Pathologie und Pharmakologie 26.6, 401-411.

Lewin, Louis. 1998. Phantastica: Narcotic and Stimulating Drugs, Their Use and Abuse. Trans by P.H.A. Wirth. Rochester: Park Street Press.

Ludlow, Fitz Hugh. 1910. 'The Hasheesh Eater,' The Equinox 1.4, 135-146.

Lytton, Edward Bulwer. 1861. Zanoni, Vol.1. Edinburgh: William Blackwood \& Sons.

Majercik, Ruth. 1989. The Chaldean Oracles: Text, Translation, and Commentary. Leiden: E.J. Brill.

Maslow, Abraham. 1964. Religions, Values, and Peak Experiences. Columbus: Ohio State University Press.

Murray, Nicholas. 2003. Aldous Huxley: An English Intellectual. London: Abacus.

Nordau, Max. 1895 [1892]. Degeneration. New York: D. Appleton \& Co.

Pasi, Marco. 2012. 'The Varieties of Magical Experience: Aleister Crowley's Views on Occult Practice.' In Henrik Bogdan \& Martin Starr (eds), Aleister Crowley and Western Esotericism. New York: Oxford University Press, 73-87.

Regardie, Israel. 1994. 'Roll Away the Stone.' In Israel Regardie and Aleister Crowley, Roll Away the Stone and The Herb Dangerous. North Hollywood: Newcastle Publishing, 1-65.

Regardie, Israel. 2014. The Eye in the Triangle: An Interpretation of Aleister Crowley. Las Vegas: New Falcon Publications.

Rogers, Matthew. 2012. 'Frenzies of the Beast: The Phaedran Furores in the Rites and Writings of Aleister Crowley.' In Henrik Bogdan \& Martin Starr (eds), Aleister Crowley and Western Esotericism. New York: Oxford University Press, 209-225.

Suster, Gerald. 1989. Crowley's Apprentice: The Life and Ideas of Israel Regardie. London: Rider. 
Sutin, Lawrence. 2000. Do What Thou Wilt: A Life of Aleister Crowley. New York: St. Martin's Griffin.

Symonds, John. 1958. The Magic of Aleister Crowley. London: Frederick Muller.

Symonds, John. 1971. The Great Beast: The Life and Magick of Aleister Crowley. London: Macdonald.

Whineray, E.P. 1909. 'A Pharmaceutical Study of Cannabis Sativa (Being a Collation of Facts as Known at the Present Date),' The Equinox 1.1, 233-255.

Wilson, Robert Anton. 2000. Sex, Drugs and Magick, second edition. Tempe: New Falcon Publications.

Wilson, Robert Anton. 2014. 'Introduction.' In Israel Regardie, The Eye in the Triangle: An Interpretation of Aleister Crowley. Las Vegas: New Falcon Publications, xix-xxvi.

Webb, Don. 2013. Overthrowing the Old Gods: Aleister Crowley and the Book of the Law. Rochester: Inner Traditions.

Webb, James. 1976. The Occult Establishment. La Salle: Open Court.

\footnotetext{
${ }^{1}$ While Crowley's parents belonged to the Plymouth Brethren sect, his father Edward, who was an itinerant preacher, came from a wealthy Quaker family, who had made their fortune in the brewing industry.

2 'Ethyl Oxide' was dictated to Leah Hirsig ('Alostrael') on May 30, 1923 in Tunisia (see Crowley 1996: 33).

3 Posthumously published, Crowley wrote this admirably candid diary during a period of rehabilitation in Fontainebleu. It was originally entitled, 'Liber TzBA Vel NIKH.'

${ }^{4}$ Between 1909 and 1914 Crowley's journal The Equinox published a wide range of material, from poetry and short stories to discussions of yoga and the occult. The title reflects the fact that it was published twice a year on the vernal and autumnal equinoxes. Overall, there were ten issues.

5 This was the motto for Crowley's short-lived journal, The Equinox, 'the official organ' of the A $\therefore$ A $\therefore$ - the occult order he established following his departure from the Hermetic Order of the Golden Dawn.

${ }^{6}$ The phrase is taken from The Chaldean Oracles. There are various translations of available online. Crowley used the version edited by William Wynn Westcott. However, for a good translation and scholarly commentary, see Majercik 1989: 'the initiate would aid in releasing the soul [loosening the girders of the soul] by engaging in certain breathing exercises' (1989: 38).

7 Marco Pasi is, understandably, skeptical that he ever managed to free himself from addiction, noting that, following his failed attempt at Fontainebleau, he continued using until his death (2014: 17).

${ }^{8}$ In 1924, he published the influential study of psychoactive plants, Phantastica: Narcotic and Stimulating Drugs, Their Use and Abuse. Originally published in German, it was translated into English in 1933.

9 It is sometimes mentioned in code. Because the initials of the drug, 'A' and 'L,' correspond to Hebrew letters $\times($ aleph) and $ל$ (lamedh), in accordance with gematria, Crowley assigned it the number 31: $\aleph=1$; $ל=30$ (see, Rogers 2012: 215; see also the table in Crowley 1996: 230).

10 Throughout his discussion, his estimation of Crowley is almost entirely lacking in critical distance and, indeed, approaches hagiography. For example, not only does he claim that his 'fine classical and scientific education at Cambridge' (omitting to mention that he failed to complete his studies) and 'his mountaineering exploits' equipped him to 'tackle the problem of psychedelic drugs' (how, he does not say), but he goes on to insist that 'Crowley was an experimental mystic of the highest magnitude. He had practiced yoga and magical techniques assiduously for many years until he had achieved a thoroughgoing
} 
mastery over both Eastern and Western methods. All of these rare skills were eventually brought to bear on his experimentation with a variety of drugs.' Moreover, Crowley's writings, he claims, 'bear witness to, and provide massive evidence of, his objective and scientific attitude to the whole process.' This is actually very far from being the case (see Regardie 1994: 42-43).

11 'I should have been assigned publicly my proper place among my peers of the past without difficulty had it not been for one fatal fact. My point of view is so original, my thoughts so profound, and my allusions so recondite, that superficial readers, carried away by the sheer music of the words, found themselves, so to speak, intoxicated and unable to penetrate to the pith' (Crowley, quoted in Booth 2000: 244). 